\title{
KANDUNGAN BAHAN ORGANIK SEDIMEN DAN KADAR H2S AIR DI DALAM DAN DI LUAR TEGAKAN MANGROVE DESA BEDONO, KABUPATEN DEMAK.
}

\author{
Content of Sediment Organic Materials and H2S in the Water in the Inside and Outside of Bedono Mangrove \\ Area, Regency of Demak
}

\author{
Halimatus Sa'diyah, Norma Afiati*), Pujiono Wahyu Purnomo \\ Program Studi Manajemen Sumberdaya Perairan
}

Departemen Sumberdaya Akuatik Fakultas Perikanan dan Ilmu Kelautan Universitas Diponegoro

Jl. Prof. Soedharto, SH, Semarang, Jawa Tengah-50275, Telp/Fax. +62247474698

Email: halimatus.sadiyah2995@gmail.com

\begin{abstract}
ABSTRAK
Kawasan mangrove dapat memproduksi bahan organik dari proses dekomposisi serasah yang jatuh yang menjadi penyuplai nuterien ke lingkungannya. Proses tersebut menggunakan oksigen terlarut yang apabila oksigen terlarut habis maka proses tersebut beralih ke proses dekomposisi secara anaerob yang menyebabkan terbentuknya senyawa $\mathrm{H}_{2} \mathrm{~S}$. Penelitian ini bertujuan untuk mengetahui perbedaan kandungan bahan organik sedimen dan kadar $\mathrm{H}_{2} \mathrm{~S}$ air di dalam dan di luar kawasan mangrove serta untuk mengetahui hubungan kandungan kadar $\mathrm{H}_{2} \mathrm{~S}$ air dengan bahan organik sedimen dan oksigen terlarut di kawasan mangrove desa Bedono. Metode penelitian adalah metode survey. Penelitian ini dilakasanakn pada bulan Mei- Juni 2017 di lokasi yang mewakili kawasan mangrove dan lingkungan sekitarnya. Data yang diukur adalah suhu air, kecerahan, kedalaman, kecepatan arus, oksigen terlarut, $\mathrm{pH}$, bahan organik sedimen dan $\mathrm{H}_{2} \mathrm{~S}$ air yang dilaksanakan empat kali dengan selang pengukuran dua minggu. Hasil yang didapat yaitu suhu air $28-31^{\circ} \mathrm{C}$, kecerahan $14,5-68 \mathrm{~cm}$, kedalaman 33-165 cm, kecepatan arus 0-0,1 m/s, oksigen terlarut, $\mathrm{pH} 5-6$, bahan organik sedimen 7,73-20,27\%, $\mathrm{H}_{2} \mathrm{~S}$ air 0,003-0,037 mg/l. Kandungan bahan organik sedimen dan kadar $\mathrm{H}_{2} \mathrm{~S}$ air tertinggi di dalam kawasan mangrove dengan rata-rata $16,36 \%$ dan $0,031 \mathrm{mg} / \mathrm{l}$, dan terendah di luar kawasan mangrove dengan rata-rata 9,78\% dan $0,01 \mathrm{mg} / \mathrm{l}$. Kadar $\mathrm{H}_{2} \mathrm{~S}$ tinggi di dalam kawasan mangrove dan lebih rendah di luar kawasan mangrove. Kadar $\mathrm{H}_{2} \mathrm{~S}$ air dengan bahan organik sedimen dan oksigen terlarut berhubungan linier dengan persamaan $\mathrm{H} 2 \mathrm{~S}=0,027+$ 0,001BOS- 0,006 DO ( $\mathrm{r}=0,7246, \mathrm{BOS}=$ Bahan Organik Sedimen, DO= Dissolved Oxygen $)$.
\end{abstract}

Kata Kunci: Bahan Organik Sedimen; $\mathrm{H}_{2} \mathrm{~S}$ Air; Mangrove; Desa Bedono

\section{ABSTRACT}

Mangroves produce organic matter from the decomposition of falling leaves, twigs etc, which supply nutrient to the environment. The process uses dissolved oxygen; when dissolved oxygen exhausted, it switches into anaerobic decomposition which causes the formation of $\mathrm{H}_{2} \mathrm{~S}$ compounds. This study aims to knowing differences in sediment organic materials and $\mathrm{H}_{2} \mathrm{~S}$ within and adjacent of mangrove areas and to determine the relation of $\mathrm{H}_{2} \mathrm{~S}$ with sediment organic materials and dissolved oxygen in the mangrove areas of Bedono. Survey method is refered, and the study was conducted in May - June 2017 on locations representing mangrove areas and the surrounding environment. The data measured are water temperature, brightness, depth, current speed, dissolved oxygen, $\mathrm{pH}$, sediment organic materials and $\mathrm{H}_{2} \mathrm{~S}$ in the water. Sampling was conducted four times every fortnight. The result of the water temperature is $28-31^{\circ} \mathrm{C}$, brightness 14.5 to $68 \mathrm{~cm}, 33-165 \mathrm{~cm}$ depth, current speed 0-0.1 m/s, dissolved oxygen 2-5,2 mg/l, pH 5-6, sediment organic material 7,73 to $20.27 \%, \mathrm{H}_{2} \mathrm{~S} 0.003$ to $0.037 \mathrm{mg} / \mathrm{l}$. Sediment organic materials and $\mathrm{H}_{2} \mathrm{~S}$ were highest within the mangrove area, with an average $16.36 \%$ and $0.031 \mathrm{mg} / \mathrm{l}$, and the lowest outside of mangrove area with an average $9.78 \%$ and $0.01 \mathrm{mg} / \mathrm{l} . \mathrm{H}_{2} \mathrm{~S}$ higher in the inside of the mangrove areas compared to the outside of it. The relation of $\mathrm{H}_{2} \mathrm{~S}$ with sediment organic materials and dissolved oxygen is linearly related according to the equation H2S=0.027+0.001SOM$0.006 D O(r=0.7246$, SOM = Sediment Organic Materials, DO= Dissolved Oxygen $)$.

Key Words: Organic Materials in the Sediment; $\mathrm{H}_{2} \mathrm{~S}$ in the Water; Mangrove; Bedono Village *)penulis penanggung jawab

\section{PENDAHULUAN}

Hutan mangrove adalah habitat dari berbagai macam biota, sebagai pelindung dan penahan dari intrusi air laut, sebagai perangkap sedimen, melindungi pantai dari abrasi, dan merupakan salah satu pemasok nutrisi yang berasal dari serasah ke lingkungannya. Menurut Kuenzer (2011), kawasan mangrove yang telah mengalami suksesi tahap akhir mendukung kehidupan biota di sekitarnya yang didasarkan pada kemampuan mangrove

\footnotetext{
${ }^{\circ}$ Copyright by Management of Aquatic Resources (MAQUARES)
} 
untuk memasok bahan organik. Serasah mangrove berupa daun dan ranting yang jatuh menjadi bahan organik yang terbentuk melalui proses dekomposisi.

Tergenangnya kawasan mangrove menyebabkan penambahan bahan organik yang terus menerus di kawasan tersebut. Menurut Nugroho et. al. (2013), subtrat lumpur pada kawasan mangrove banyak mengandung bahan organik. Hal ini karena di daerah tersebut biasanya gerakan air relatif lemah, sehingga serasah mangrove akan mengendap di dasar perairan sebagai bahan organik. Bahan organik yang berlebih akan membuat proses dekomposisi berjalan terus menerus menyebabkan oksigen terlarut semakin tipis dan akhirnya habis, sehingga proses tersebut kemudian beralih ke proses anaerob. Apabila di perairan tidak terdapat oksigen dan nitrat, maka sulfat berperan sebagai sumber oksigen dalam proses oksidasi yang dilakukan oleh bakteri anaerob, sehingga pada kondisi tersebut dapat terbentuk hidrogen sulfida (Libes, 1992).

Menurut Chafid et. al. (2012), Desa Bedono, Kecamatan Sayung, Demak adalah kawasan pesisir yang sebagian besar wilayahnya untuk tempat hidup bagi ekosistem mangrove. Pada tahun 1980-an lahan mangrove di desa Bedono dikonversi menjadi tambak udang. Hal tersebut memicu kerusakan lahan mangrove akibat berkurangnya lahan penyangga dan saat tambak tidak produktif, maka dibiarkan begitu saja oleh masyarakat. Tahun 2004, Lembaga Swadaya Masyarakat OISCA melakukan penanaman kembali pohon mangrove.

Gas $\mathrm{H}_{2} \mathrm{~S}$ adalah gas yang beracun, apabila kadar gas ini berlebihan di suatu perairan, maka gas tersebut dapat membahayakan bagi kehidupan biota di lingkungan tersebut. Gas $\mathrm{H}_{2} \mathrm{~S}$ timbul sebagai akibat dari perombakan bahan organik yang tertimbun di sedimen. Hal tersebut dapat terjadi karena kawasan mangrove adalah kawasan yang biasanya selalu terendam oleh air. Menurut baku mutu air laut untuk wisata bahari sesuai Keputusan Menteri Negara Lingkungan Hidup kandungan $\mathrm{H}_{2} \mathrm{~S}$ adalah 0,03 mg/l. Menurut Poppo et. al. (2009), tingginya kandungan hidrogen sulfida pada air limbah disebabkan karena proses pembusukkan bahan-bahan organik yang mengandung belerang oleh bakteri anaerob.

\section{MATERI DAN METODE PENELITIAN} Materi

Materi penelitian ini adalah sampel sedimen dan air, serta parameter Fisika-Kimia meliputi suhu, kecerahan, kedalaman, kecepatan arus, $\mathrm{pH}$, bahan organik sedimen dan $\mathrm{H}_{2} \mathrm{~S}$ air. Pengambilan sampel di lakukan di tujuh titik yang mewakili kawasan luar, pinggir, dan dalam tegakan mangrove.

Metode

Penelitian bersifat survey yaitu melakukan penyelidikan untuk memperoleh fakta dari gejala yang ada dan mencari keterangan secara faktual. Sampel air dan sedimen diambil di tujuh titik sampling kawasan mangrove. Pengambilan sampel sedimen untuk analisis bahan organik menggunakan grab sampler dan pengambilan sample air untuk analisis kadar $\mathrm{H}_{2} \mathrm{~S}$ diambil secara langsung. Sampel air dimasukkan dalam botol plastik dan sampel sedimen diwadahi dalam kantong plastik, disimpan sementara dalam cool box untuk selanjutnya dianalisis. Kandungan bahan organik sedimen dianalisis di Laboratorium Departemen Teknologi Hasil Perikanan, UNDIP Semarang dan kadar $\mathrm{H}_{2} \mathrm{~S}$ air di Balai Pengujian dan Peralatan, Semarang.

\section{Analisis Data}

Data penelitian dianalisis menggunakan software SPSS Stastistics 16. Khususnya untuk melihat hubungan antara kadar $\mathrm{H}_{2} \mathrm{~S}$ air dengan bahan organik sedimen dan oksigen terlarut menggunakan analisis regresi berganda.

\section{HASIL DAN PEMBAHASAN}

Penelitian dilakukan di kawasan mangrove desa Bedono, Kecamatan Sayung, Kabupaten Demak. Kawasan Mangrove desa Bedono mempunyai sebaran yang beragam. Sebagian besar kawasan mangrove tersebut berada di dukuh Senik yang berada di perbatasan antara area pertambakan dan perairan laut Jawa. Sebagian kawasan mangrove lainnya berada di daerah yang berdekatan dengan pemukiman dan letaknya terpisah. Selain sebagai daerah konservasi, kawasan mangrove berperan sebagai penahan ombak dan abrasi di kawasan tersebut. Jenis mangrove yang mendominasi adalah jenis Api-api (Avicennia sp.) dan Bakau (Rhizophora sp.). Setiap wilayah di kawasan mangrove tersebut memiliki keanekaragaman masing-masing, dimana ada wilayah yang hanya ditumbuhi jenis Bakau ataupun Api-api saja, namun ada wilayah yang ditumbuhi oleh keduanya.

\section{Hasil Pengukuran Variabel Fisika dan Kimia Air}

Pengukuran variabel fisika dan kimia pada penelitian ini yaitu suhu air, kecerahan, kedalaman, kecepatan arus, oksigen terlarut, $\mathrm{pH}$ air, bahan organik sedimen, dan kadar $\mathrm{H}_{2} \mathrm{~S}$ air yang tersaji dalam tabel 2 .

\footnotetext{
${ }^{\circledR}$ Copyright by Management of Aquatic Resources (MAQUARES)
} 


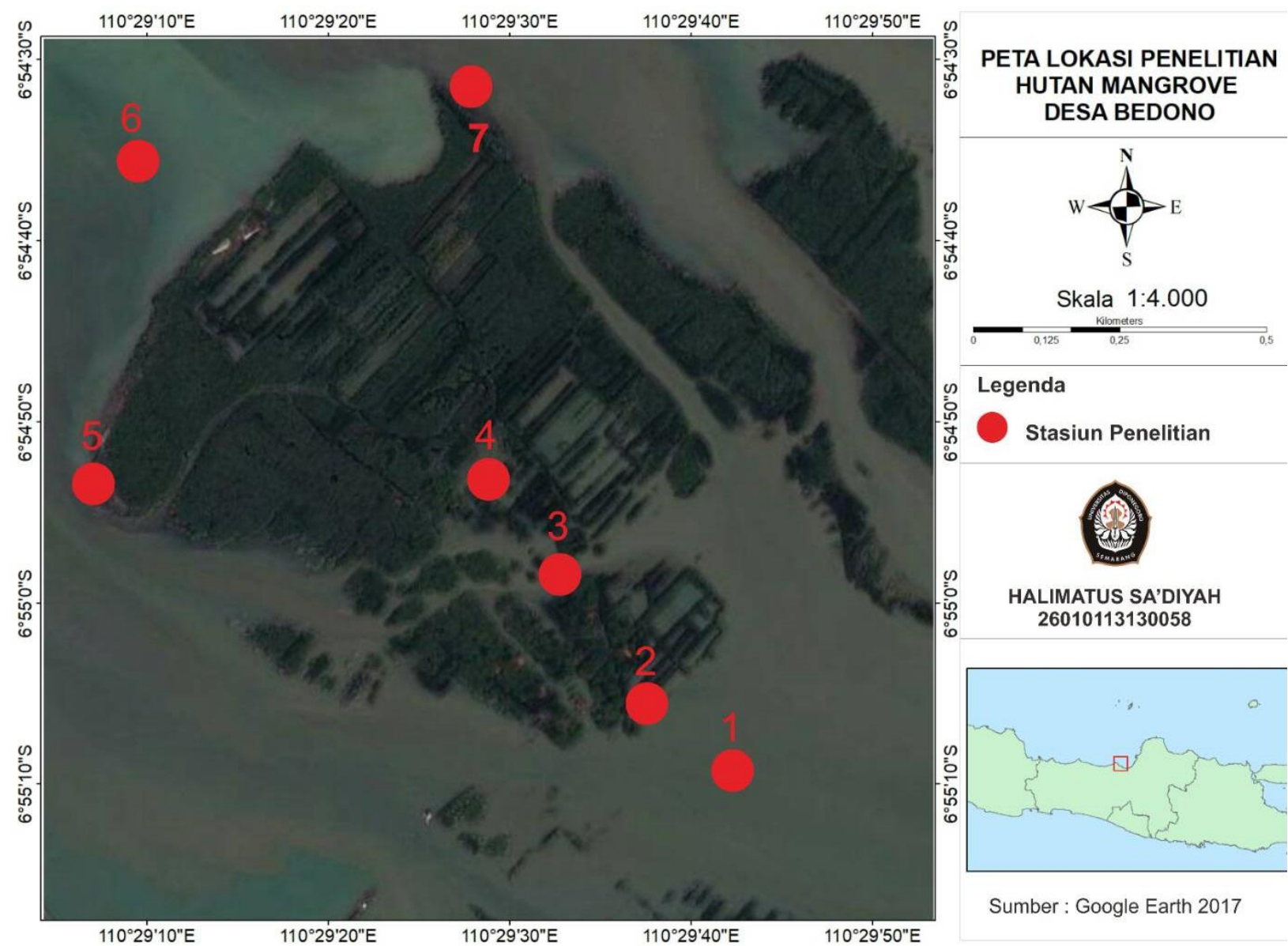

Gambar 1. Peta Lokasi Penelitian

Tabel 1. Koordinat Titik Sampling

\begin{tabular}{cccl}
\hline $\begin{array}{c}\text { Titik } \\
\text { Sampling }\end{array}$ & Garis Lintang & Garis Bujur & \multicolumn{1}{c}{ Keterangan } \\
\hline 1 & $6^{\circ} 54^{\prime} 52.16^{\prime \prime}$ & $110^{\circ} 29^{\prime} 28.72^{\prime \prime}$ & Di luar kawasan mangrove \\
2 & $6^{\circ} 54^{\prime} 57.78^{\prime \prime}$ & $110^{\circ} 29^{\prime} 32.77^{\prime \prime}$ & Di pinggir kawasan mangrove \\
3 & $6^{\circ} 55^{\prime} 4.67^{\prime \prime}$ & $110^{\circ} 29^{\prime} 37.63^{\prime \prime}$ & Di dalam kawasan mangrove \\
4 & $6^{\circ} 54^{\prime} 52.72^{\prime \prime}$ & $110^{\circ} 29^{\prime} 9.35^{\prime \prime}$ & Di dalam kawasan mangrove \\
5 & $6^{\circ} 54^{\prime} 32.72^{\prime \prime}$ & $110^{\circ} 29^{\prime} 27.40^{\prime \prime}$ & Di pinggir kawasan mangrove \\
6 & $6^{\circ} 55^{\prime} 7.29 "$ & $110^{\circ} 29^{\prime} 41.29 "$ & Di luar kawasan mangrove \\
7 & $6^{\circ} 54^{\prime} 35.10^{\prime \prime}$ & $110^{\circ} 29^{\prime} 11.56^{\prime \prime}$ & Di pinggir kawasan mangrove \\
\hline
\end{tabular}

Tabel 2. Variabel Fisika dan Kimia di Kawasan Mangrove Desa Bedono pada bulan Mei-Juni 2017

\begin{tabular}{|c|c|c|c|c|c|c|c|c|c|c|c|c|c|c|c|c|c|c|c|c|c|c|c|c|}
\hline & \multicolumn{4}{|c|}{ Suhu Air $\left({ }^{\circ} \mathbf{C}\right)$} & \multicolumn{4}{|c|}{ Kecerahan (cm) } & \multicolumn{4}{|c|}{ Kedalaman (cm) } & \multicolumn{4}{|c|}{$\begin{array}{l}\text { Kecepatan Arus } \\
(\mathbf{m} / \mathbf{s})\end{array}$} & \multicolumn{4}{|c|}{ DO (mg/l) } & \multicolumn{4}{|c|}{ pH } \\
\hline & 1 & 2 & 3 & 4 & 1 & 2 & 3 & 4 & 1 & 2 & 3 & 4 & 1 & 2 & 3 & 4 & 1 & 2 & 3 & 4 & 1 & 2 & 3 & 4 \\
\hline 1 & 28 & 28 & 28 & 31 & 21 & 25 & 16,5 & 42 & 64 & 71 & 77 & 94 & 0,1 & 0 & 0 & 0 & 3,6 & 3,6 & 3,2 & 3,6 & 6 & & 6 & 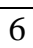 \\
\hline 2 & 28 & 28 & 28 & 31 & 31 & 27,5 & 17 & 36 & 63 & 68 & 80 & 76 & 0 & 0 & 0 & 0 & 3,6 & 3,2 & 2,8 & 3,2 & 6 & 6 & 6 & ( \\
\hline 3 & 28 & 28 & 29 & 30 & $\infty$ & 19 & & 22 & 3. & 41 & 66 & 53 & 0 & 0 & 0 & 0 & 3,2 & 2 & 2 & 2,8 & 6 & 6 & 6 & \\
\hline 4 & 28 & 28 & 29 & 30 & 30 & 20,5 & 20,5 & 27,5 & 51 & 56 & 89 & 89 & 0,1 & 0,1 & 0,1 & 0 & 2,4 & 2.8 & 2 & 2,4 & 6 & 6 & 6 & \\
\hline 5 & 29 & 29 & 30 & 29 & 52 & 39 & 23 & 22,5 & 79 & 75 & 94 & 49 & 0 & 0 & 0 & 0 & 4 & 4 & 5,2 & 4,4 & 6 & 6 & 6 & 6 \\
\hline 6 & 29 & 29 & 30 & 30 & 68 & 61 & 57 & 51 & 144 & 132 & 165 & 135 & 0,1 & 0,1 & 0,1 & 0,1 & 4,4 & 4 & 5,2 & 4,8 & 5 & 6 & 6 & 6 \\
\hline 7 & 29 & 29 & 30 & 29 & 33 & 24 & 21,5 & 31 & 61 & 59 & 89 & 84 & 0,1 & 0,1 & 0 & 0 & 3,6 & 3,6 & 3,6 & 3,6 & 6 & 6 & 6 & 6 \\
\hline
\end{tabular}

\section{Jenis, Umur, dan Kondisi Tegakan Mangrove}

Variabel hayati yang diamati adalah jenis mangrove, umur mangrove, dan kondisi tegakan mangrove.

Hasil dari pengamatan tersebut adalah sebagai berikut:

${ }^{\circ}$ Copyright by Management of Aquatic Resources (MAQUARES) 
Tabel 3. Hasil Pengamatan Variabel Hayati Mangrove

\begin{tabular}{cccl}
\hline \multirow{2}{*}{ Titik } & \multicolumn{3}{c}{ Mangrove } \\
\cline { 2 - 4 } & Spesies & Umur & \multicolumn{1}{c}{ Kondisi Tegakan } \\
\hline 1 & - & - & Tidak terdapat tegakan mangrove \\
2 & Rhizophora sp. & Muda & Tegakan cukup rapat \\
3 & Rhizophora sp. & Muda & Lebat tetapi tegakan jarang \\
4 & Rhizophora sp. & Tua & Tegakan rapat dan lebat \\
& Avicennia sp. & & \\
5 & Avicennia sp. & Tua & Rusak dan banyak yang mengering \\
6 & - & - & Tidak terdapat tegakan mangrove \\
7 & Rhizophora sp. & Tua & Banyak yang mengering dan tumbang \\
\hline
\end{tabular}

\section{Bahan Organik Sedimen dan Kadar $\mathrm{H}_{2} \mathrm{~S}$ Air}

Kandungan bahan organik sedimen dan kadar $\mathrm{H}_{2} \mathrm{~S}$ air di kawasan mangrove desa Bedono adalah sebagai berikut:

Tabel 4. Kandungan Bahan Organik Sedimen (\%) di Kawasan Mangrove pada Bulan Mei-Juni 2017

\begin{tabular}{|c|c|c|c|c|c|}
\hline \multirow[b]{2}{*}{ Titil } & \multicolumn{4}{|c|}{ Pengulangan } & \multirow{2}{*}{$\begin{array}{c}\text { Rata- } \\
\text { rata } \pm \text { SD }\end{array}$} \\
\hline & I & II & III & IV & \\
\hline 1 & 10.345 & 10.485 & 11.990 & 11.150 & $10,99 \pm 0,75$ \\
\hline & 15.900 & 16.2 & & 13.385 & 14, \\
\hline & 15.580 & 15.1 & & 15.985 & 15, \\
\hline & 13.280 & 14.2 & 20.275 & 19.140 & 16,7 \\
\hline 5 & 15.575 & 15.450 & 13.115 & 12.400 & $14,13 \pm 1,61$ \\
\hline & 9.900 & 8.880 & 7.730 & 7.745 & $8,56 \pm 1,04$ \\
\hline & 14.725 & 15.845 & 12.465 & 11.455 & $13,62 \pm 2,0$ \\
\hline
\end{tabular}

Tabel 5. Kadar $\mathrm{H}_{2} \mathrm{~S}$ Air $\left(10^{-2} \mathrm{mg} / \mathrm{l}\right)$ di Kawasan Mangrove pada Bulan Mei-Juni 2017

\begin{tabular}{cccccc}
\hline \multirow{2}{*}{ Titik } & \multicolumn{4}{c}{ Pengulangan } & \multicolumn{2}{c}{\begin{tabular}{c} 
Rata- \\
\cline { 2 - 5 }
\end{tabular}} & I & II & III & IV & rata $\pm S D$ \\
\hline 1 & 1,4 & 1,6 & 2,2 & 1,3 & $1,6 \pm 0,4$ \\
2 & 2,9 & 1,8 & 2,5 & 3,2 & $2,6 \pm 0,6$ \\
3 & 1,8 & 3,1 & 2,5 & 3,6 & $2,8 \pm 0,8$ \\
4 & 3,6 & 3,7 & 3,1 & 3,5 & $3,5 \pm 0,3$ \\
5 & 1,1 & 1,6 & 2,6 & 2,1 & $1,9 \pm 0,6$ \\
6 & 0,4 & 0,6 & 0,3 & 0,6 & $0,5 \pm 0,1$ \\
7 & 1,5 & 1,6 & 1,8 & 2,4 & $1,8 \pm 0,4$ \\
\hline
\end{tabular}

Hasil uji analisis ragam, didapatkan $\mathrm{F}=9,662$ dengan signifikansi 0,000 , sehingga terdapat perbedaan signifikan kandungan bahan organik sedimen antar stasiun di kawasan mangrove desa Bedono. Menurut Menurut Reynold (1971) dalam Hartoko et. al., (2013), klasifikasi kandungan bahan organik dalam sedimen < $3.5 \%$ tergolong sangat rendah, 3.5-7 \% tergolong rendah, 7-17\% tergolong sedang, 17-35\% tergolong tinggi dan kandungan bahan organik dalam sedimen $>35 \%$ tergolong sangat tinggi. Kandungan bahan organik sedimen tertinggi dalam penelitian ini $=16,74 \%$ berada di dalam tegakan mangrove yang menurut Reynold (1971) dalam Hartoko et. al., (2013) tergolong sedang, kemudian di pinggir tegakan mangrove dengan tingkat bahan organik sedimen sedang, dan kandungan terendah yang juga tergolong sedang berada di luar tegakan mangrovenya.

Berdasarkan hasil uji analisis ragam kadar $\mathrm{H}_{2} \mathrm{~S}$, didapatkan $\mathrm{F}=14,404$ dengan signifikansi 0,000. Hal ini menunjukkan perbedaan signifikan kadar $\mathrm{H}_{2} \mathrm{~S}$ antar stasiun di kawasan mangrove desa Bedono. Sebaran lokasi kadar $\mathrm{H}_{2} \mathrm{~S}$ sama dengan sebaran lokasi kandungan bahan organik. Kadar $\mathrm{H}_{2} \mathrm{~S}$ yang tertinggi berada di dalam tegakan mangrove, kemudian di pinggir tegakan mangrove, dan kandungan terendah berada di luar tegakan mangrove.

\section{Pembahasan}

\section{Variabel Fisika dan Kimia Air}

Suhu dipengaruhi oleh kecerahan di perairan tersebut. Suhu air di kawasan mangrove desa Bedono berbeda di setiap titiknya berkisar antara $28-31^{\circ} \mathrm{C}$. Rata-rata suhu terendah kawasan mangrove desa Bedono berada di dalam kawasan dan suhu tertinggi berada di luar kawasan mangrove. Peningkatan suhu air mempengaruhi kecepatan penguraian bahan organik oleh bakteri. Peningkatan dekomposisi bahan organik akan mempengaruhi kandungan oksigen terlarut yang membuatnya semakin menipis, yang selanjutnya akan membuat kandungan $\mathrm{H}_{2} \mathrm{~S}$ di kawasan tersebut meningkat. Menurut Effendi (2003), aktivitas mikroorganisme memerlukan suhu optimum yang berbeda-beda. Setiap peningkatan $10^{\circ} \mathrm{C}$ akan meningkatkan proses penguraian bahan organik dan konsumsi oksigen.

Kecerahan di perairan mangrove dipengaruhi oleh kedalaman dan kekeruhan perairan. Stasiun di luar tegakan mangrove memiliki kecerahan tertinggi dengan kandungan bahan organik sedimen dan kadar $\mathrm{H}_{2} \mathrm{~S}$ air

\footnotetext{
${ }^{\circ}$ Copyright by Management of Aquatic Resources (MAQUARES)
} 
yang rendah, dan stasiun di dalam kawasan mangrove memiliki kecerahan terendah dengan kandungan bahan organik sedimen dan $\mathrm{H}_{2} \mathrm{~S}$ yang tinggi. Semakin rendah tingkat kecerahan, semakin kecil intensitas cahaya matahari yang masuk ke dalam perairan dasar. Menurut Odum (1993), oksigen di dalam air digunakan oleh bakteri dalam proses penguraian bahan organik. Penguraian bahan organik secara terus menerus dengan kandungan oksigen terlarut yang semakin habis akan mengakibatkan terbentuknya $\mathrm{H}_{2} \mathrm{~S}$ di perairan tersebut.

Angka kedalaman tertinggi berada di arah laut lepas dan tidak terdapat tegakan mangrove (titik 6). Kedalaman dipengaruhi oleh banyak sedikitnya bahan organik yang mengendap di dasar perairan tersebut. Menurut Apriliana et.al. (2014), kedalaman suatu perairan dipengaruhi oleh banyak sedikitnya bahan organik yang mengendap di perairan dasar serta tumbuhan air yang berada di permukaan perairan. Kedalaman sangat berkaitan erat dengan oksigen terlarut, yaitu semakin bertambah kedalaman perairan, maka konsentrasi oksigen terlarut semakin berkurang.

Rata-rata kecepatan arus di kawasan mangrove desa Bedono adalah $0 \mathrm{~m} / \mathrm{s}$. relatf kecilnya arus di suatu perairan menyebabkan zat dalam air akan lebih mudah untuk mengendap, sehingga kandungan bahan organik di area tersebut akan meningkat. Menurut Roswaty et. al. (2014), laut cenderung mempunyai arus yang kuat dan material yang berukuran besar (pasir) yang mudah mengendap. Lumpur yang mempunyai ukuran butir yang lebih kecil dari pasir mengendap bila arus pada perairan mulai lemah seperti di daerah muara sungai.

Angka pH perairan kawasan mangrove desa Bedono adalah 5-6 dengan rata-rata setiap titiknya adalah 6 . Angka tersebut lebih rendah dari angka $\mathrm{pH}$ air laut yang seharusnya yaitu 8-9, sehingga dapat mengakibatkan terbentuknya $\mathrm{H}_{2} \mathrm{~S}$ dalam air. Menurut Poppo et. al. (2009), rendahnya angka $\mathrm{pH}$ perairan disebabkan oleh proses penguraian bahan organik oleh bakteri anaerob yang menghasilkan asam organik. Menurut Effendi (2003), toksisitas $\mathrm{H}_{2} \mathrm{~S}$ meningkat dengan penurunan angka $\mathrm{pH}$ karena pada $\mathrm{pH} 5$ sulfur berada dalam bentuk $\mathrm{H}_{2} \mathrm{~S}$.

Rata-rata oksigen terlarut di luar kawasan tegakan mangrove lebih tinggi, diikuti di pinggir kawasan tegakan mangrove, dan oksigen terlarut yang rendah berada di dalam kawasan tegakan mangrove. Semakin tinggi kandungan oksigen terlarut, maka perairan tersebut mempunyai pasokan yang cukup untuk proses dekomposisi bahan organik, sehingga tidak bergeser ke proses anaerob. Proses anaerob dalam dekomposisi bahan organik dapat menyebabkan terbentuknya $\mathrm{H}_{2} \mathrm{~S}$. Hasil penelitian ini menunjukkan kandungan bahan organik di dalam kawasan tegakan mangrove lebih tinggi dibandingkan kawasan di pinggir maupun di luar tegakan mangrove. Menurut Pantjara et. al. (2010), kandungan oksigen terlarut dalam air sering berfluktuasi, oksigen terlarut berperan penting dalam kehidupan biota di dalam suatu perairan, termasuk bakteri pengurai di kawasan tersebut. Berkurangnya oksigen terlarut secara terus-menerus akan mengubah proses penguraian bahan organik yang semula aerob berganti menjadi anaerob. Menurut Purnamawati (2009), penurunan angka oksigen terlarut menggambarkan adanya perubahan komposisi bakteri pengurai yang terdapat di perairan dasar sehingga memungkinkan munculnya kelompok bakteri anaerob fakultatif.

\section{Jenis, Umur, dan Kondisi Tegakan Mangrove}

Mangrove yang teramati pada saat penelitian terdiri dari dua jenis yaitu Rhizophora sp. dan Avicennia sp. Hal ini sesuai dengan pernyataan Chafid et. al. (2012), spesies mangrove yang banyak ditemukan di kawasan pesisir Desa Bedono, Kecamatan Sayung, Kabupaten Demak adalah Avicennia marina dan Rhizophora mucronata. Jenis mangrove Rhizophora sp. lebih sering ditemukan di lokasi penelitian dibandingkan jenis Avicennia sp., tetapi tegakan Avicennia sp. mendominasi di pinggir kawasan mangrove yang dekat arah laut (titik 5, Tabel 3) dimana tegakannya meluas sampai ke kawasan yang menghadap langsung ke laut bebas.

Menurut Suwardi et. al. (2014), perbedaan sebaran mangrove sangat tergantung pada faktor lingkungan, antara lain pasang surut yang secara tidak langsung mengontrol ketinggian muka air, tingginya muka air, dan cahaya yang berpengaruh terhadap pertumbuhan anakan dari species intoleran seperti Rhizophora maupun Avicennia. Chafid et. al. (2012), menyatakan spesies Avicennia marina mendominasi lokasi penelitian kawasan pesisir Desa Bedono karena kawasan tersebut sesuai untuk pertumbuhannya. Namun, pada saat pengamatan tegakan Avicennia sp. mulai menunjukkan kerusakan. Hal tersebut mungkin karena gelombang laut yang langsung mengena ke kawasan mangrove tersebut. Menurut Chapman (1976), Avicennia sp. merupakan spesies perintis dalam komunitas mangrove, karena Avicennia sp. mempunyai ketahanan yang baik terhadap pasang surut, gelombang dan toleran terhadap perubahan salinitas.

\section{Sebaran Bahan Organik Sedimen dan $\mathrm{H}_{2} \mathrm{~S}$ Air}

${ }^{\odot}$ Copyright by Management of Aquatic Resources (MAQUARES) 
Kadar bahan organik sedimen di kawasan mangrove desa Bedono berbeda di setiap stasiunnya. Secara keseluruhan hasil uji menunjukkan $\mathrm{F}=9,662$ dengan signifikansi 0,000 , yang berarti terdapat perbedaan kandungan bahan organik sedimen di kawasan mangrove desa Bedono. Hasil tersebut menunjukkan adanya perbedaan kadar bahan organik sedimen di dalam tegakan mangrove, di pinggir tegakan mangrove, dan di luar tegakan mangrove. Menurut Roswaty et. al. (2014), semakin halus sedimen, kemampuan mengakumulasi bahan organik semakin besar. Kandungan bahan organik pada umumnya akan tinggi pada sedimen berlumpur.

Di Bedono, bagian dalam kawasan mangrove yang memiliki tegakan Rhizophora sp. dan Avicennia sp. rapat dan lebat (Tabel 3) memperlihatkan kandungan bahan organik sedimen tertinggi (16,74\%; Tabel 4). Kandungan bahan organik sedimen terendah terdapat dibagian luar kawasan $(8,56 \%$, Tabel 4$)$, dicirikan tidak terdapatnya vegetasi mangrove (titik 6; Tabel 3). Adapun lokasi lain di luar kawasan (titik 1; Tabel 3) yang juga tidak ditumbuhi mangrove, kandungan bahan organik sedimennya terendah kedua $(10,99 \%)$ setelah titik 6 (titik 6; Tabel 4).

Bahan organik di lantai tegakan mangrove berasal dari mangrove itu sendiri yaitu dari serasah daun, ranting, maupun akar yang jatuh ke dasar perairan. Hal tersebut berarti mangrove memasok bahan organik ke lingkungannya, sehingga daerah tersebut memiliki kandungan bahan organik sedimen yang lebih tinggi (Kushartono, 2009). Hal ini juga diperlihatkan oleh kerapatan vegetasi yang tinggi, warna sedimen yang sangat gelap serta beraroma spesifik.

Di dalam kawasan tegakan mangrove, dua jenis mangrove yaitu Rhizophora sp. dan Avicennia sp. tumbuh rapat dan lebat. Menurut Amin et. al. (2012), di daerah mangrove, kandungan bahan organik yang tinggi dipengaruhi oleh kondisi vegetasi dan lingkungan sekitar yang masing-masing memberikan sumbangan bahan organik ke perairan. Di luar kawasan tegakan mangrove yang dikaji tidak ditemukan mangrove maupun jenis vegetasi lainnya. Spesifikasi kawasan di luar tegakan mangrove adalah mengarah ke arah laut lepas, mempunyai substrat pasir yang ukuran partikelnya lebih besar dibandingkan dengan substrat di kawasan mangrove. Menurut Ardi (2002) dan Amin et al. (2012), sedimen berpasir memiliki kandungan bahan organik lebih rendah dibandingkan sedimen lumpur, karena tekstur dan ukuran partikel yang halus memudahkan terserapnya bahan organik dengan demikian dasar perairan berlumpur cenderung mengakumulasi bahan organik yang terbawa aliran air.

Berdasarkan penelitian yang telah dilakukan di kawasan mangrove desa Bedono, didapatkan kadar $\mathrm{H}_{2} \mathrm{~S}$ air yang berbeda di setiap stasiunnya yaitu di dalam, di pinggir, dan di luar tegakan mangrove (Tabel 5). Hasil uji menunjukkan angka $\mathrm{F}=14,404$ dengan signifikansi sebesar 0,000. Hasil tersebut menunjukkan terdapat perbedaan kandungan $\mathrm{H}_{2} \mathrm{~S}$ dalam air di wilayah mangrove desa Bedono. Kadar $\mathrm{H}_{2} \mathrm{~S}$ yang berbeda tersebut berbeda antara di dalam tegakan mangrove $(0,035$ dan $0,028 \mathrm{mg} / \mathrm{l})$, di pinggir tegakan mangrove (berkisar antara 0,018- 0,025 mg/l), dan di luar tegakan mangrove (0,005 dan 0,016 mg/l, Tabel 5).

Rata-rata $\mathrm{H}_{2} \mathrm{~S}$ air di dalam tegakan mangrove paling tinggi yaitu $0,035 \mathrm{mg} / \mathrm{l}$. Rata-rata $\mathrm{H}_{2} \mathrm{~S}$ air terendah berada di luar tegakan mangrove berkisar 0,005-0,016 mg/l (titik 1 dan 6, Tabel 5). Menurut Triani et. al. (2005), variabel-variabel yang mempunyai angka berbeda seperti jenis sedimen dan kandungan oksigen mempengaruhi perbedaan kadar $\mathrm{H}_{2} \mathrm{~S}$. Dalam penelitian ini $\mathrm{H}_{2} \mathrm{~S}$ tertinggi terdapat pada wilayah yang kandungan bahan organik sedimennya juga tertinggi $(16,748 \%$ titik 4 , Tabel 4$)$ dan wilayahnya mempunyai substrat lumpur yang berwarna hitam. $\mathrm{H}_{2} \mathrm{~S}$ terendah berada di luar kawasan mangrove yang berdekatan dengan laut lepas berkisar $0,005 \mathrm{mg} / \mathrm{l}$ (titik 6, Tabel 5) yang memiliki substrat berupa pasir. Menurut Ahmad (1989), sedimen berpasir mempunyai bakteri yang menempel di permukaan butiran pasir yang lebih intensif mengoksidasi $\mathrm{H}_{2} \mathrm{~S}$. Adapun Triani et. al. (2005) berpendapat peningkatan $\mathrm{H}_{2} \mathrm{~S}$ dipengaruhi oleh besarnya populasi bakteri pengoksidasi sulfur anorganik. Populasi bakteri pengoksidasi sulfur organik lebih besar di sedimen berpasir dibandingkan sedimen liat berpasir. Lebih lanjut peneliti menyatakan penguraian bahan organik oleh bakteri memerlukan oksigen yang memadai, apabila pasokan oksigen terlarut tidak memenuhi, maka proses penguraian tersebut menjadi anaerob dan menghasilkan $\mathrm{H}_{2} \mathrm{~S}$.

\section{Hubungan Kadar $\mathrm{H}_{2} \mathrm{~S}$ Air dengan Bahan Organik Sedimen dan Dissolved Oxygen}

Berdasarkan uji regresi linier berganda, hubungan antara kadar $\mathrm{H}_{2} \mathrm{~S}$ air dengan Bahan Organik Sedimen dan oksigen terlarut di kawasan mangrove desa Bedono mempunyai persamaan $\mathrm{y}=0,027+0,001 \mathrm{x}_{1}-0,006 \mathrm{x}_{2}$. $\mathrm{F}$ hitung sebesar 13,818 dengan signifikansi 0,000 , sehingga $\mathrm{H}_{0}$ ditolak dan $\mathrm{H}_{1}$ diterima. Hasil tersebut menunjukkan bahwa bahan organik sedimen dan oksigen terlarut secara simultan mempengaruhi kadar $\mathrm{H}_{2} \mathrm{~S}$ Air. Dengan demikian berarti kadar $\mathrm{H}_{2} \mathrm{~S}$ air ipengaruhi oleh bahan organik sedimen dan oksigen terlarut, karena ${ }^{\circ}$ Copyright by Management of Aquatic Resources (MAQUARES) 
kadar $\mathrm{H}_{2} \mathrm{~S}$ berasal dari proses dekomposisi bahan organik dalam keadaan anaerob. Semakin tinggi kandungan bahan organik sedimen dan semakin rendah kandungan oksigen terlarut di perairan tersebut, maka semakin tinggi kadar $\mathrm{H}_{2} \mathrm{~S}$ airnya. Menurut Apriliana et.al. (2014), bahan organik yang tinggi akan digunakan bakteri sebagai nutrisi makanan pada proses penguraian bahan organik, sehingga jumlah bakteri yang menguraikan bahan organik meningkat seiring meningkatnya jumlah bahan organik yang masuk ke dalam perairan.

Proses penguraian bahan organik dilakukan oleh bakteri aerob, sehingga dalam prosesnya memerlukan oksigen. Jumlah oksigen terlarut semakin berkurang seiring dengan bertambahnya jumlah bakteri aerob saat proses penguraian bahan organik, sehingga hal ini akan mengakibatkan kondisi anoksik di perairan. Triani et. al. (2005) menyatakan oksigen terlarut yang rendah akan mengganggu aktivitas dan pertumbuhan bakteri pengoksidasi sulfur. Adapun menurut Purnomo et. al. (2013), kandungan bahan organik berbanding lurus dengan pertumbuhan total bakteri yang diteliti, yaitu semakin tinggi kandungan bahan organik, maka semakin tinggi kelimpahan total bakteri di perairan tersebut. Menipis dan habisnya kadar oksigen terlarut, mengakibatkan proses penguraian bahan organik dalam kondisi anoksik yang kemudian digantikan dengan bakteri anaerob fakultatif. Penguraian bahan organik pada kondisi anoksik tidak dapat berjalan secara sempurna dan dapat menimbulkan senyawa berbahaya seperti hidrogen sulfida, bahkan jumlah hidrogen sulfida dapat meningkat seiring bertambahnya bahan organik dan menurunnya oksigen terlarut. Kondisi tersebut menjadi buruk dengan keadaan lingkungan mangrove yang biasa selalu tergenang air laut. Menurut pernyataan Dent (1986), kandungan sulfur dan bahan organik yang melimpah dengan kondisi lingkungan yang tergenang dapat membentuk senyawa pirit.

\section{KESIMPULAN}

Kesimpulan yang diperoleh dari penelitian yang telah dilakukan adalah sebagai berikut:

1. Kandungan bahan organik sedimen dan kadar $\mathrm{H}_{2} \mathrm{~S}$ air tertinggi terdapat di dalam kawasan tegakan mangrove, diikuti di pinggir kawasan tegakan mangrove, dan kadar terendah di luar tegakan mangrove.

2. Kadar $\mathrm{H}_{2} \mathrm{~S}$ air di kawasan mangrove desa Bedono di pengaruhi oleh bahan organik sedimen dan kadar oksigen terlarut dengan persamaan $\mathrm{H}_{2} \mathrm{~S}=0,027+0,001 \mathrm{BOS}-0,006 \mathrm{DO}$.

\section{UCAPAN TERIMA KASIH}

Penulis mengucapkan terima kasih kepada Prof. Dr. Ir. Supriharyono, MS dan bapak Dr. Ir. Max Rudolf Muskananfola, M.Sc yang telah memberikan arahan, bimbingan, kritik dan saran dalam penulisan artikel ini. Serta semua pihak yang telah memberikan dukungan sehingga penulis dapat menyelesaikan artikel ini.

\section{DAFTAR PUSTAKA}

Ahmad, T. 1989. Shrimp aquaculture in Indonesia. In Akiyama, D.A.(ed.). Proceedings of the Southeast Asia Shrimps Farm Management Workshop. American Soybean Asociation Singapore. 109-117.

Amin, B., i. Nurrachmi., dan Marwan. 2012. Kandungan Bahan Organik Sedimen Dan Kelimpahan Makrozoobenthos Sebagai Indikator Pencemaran Perairan Pantai Tanjung Uban Kepulauan Riau. Makalah Lembaga Penelitian Universitas Riau. $9 \mathrm{hlm}$.

Ardi. 2002. Pemanfaatan Makrozoobentos sebagai Indikator Kualitas Perairan Pesisir. Program Pasca Sarjana, Institut Pertanian Bogor. Bogor. 21 hlm.

Apriliana, R., S. Rudiyanti, dan P.W. Purnomo. 2014. Keanekaragaman Jenis Bakteri Perairan Dasar Berdasarkan Tipe Tutupan Permukaan Perairan Di Rawa Pening. Management of Aquatic Resources. 3 (2): 119-128.

Chafid, M.A., R. Pribadi, dan A. Anugroho DS. 2012. Kajian Perubahan Luas Lahan Mangrove di Desa Bedono Kecamatan Sayung Kabupaten Demak Menggunakan Citra Satelit Ikonos Tahun 2004 dan 2009. Journal of Marine Research. Volume 1(2):167-173.

Chapman, V.J. 1976. Wet Coastal Ecosystems. Ecosystems of the World: 1. Elsevier Scientific Publishing Company, 428 hal.

Dent, D.L. 1986. Acid sulphate soils: A baseline for research and development. Pub. 39, Int. Land Reclamation and Improvement, Wageningen, $196 \mathrm{hlm}$.

${ }^{\odot}$ Copyright by Management of Aquatic Resources (MAQUARES) 
Effendi, H. 2003. Telaah Kualitas Air Bagi Pengelolaan Sumberdaya dan Lingkungan Perairan. Penerbit Kanisius. Yogyakarta. $259 \mathrm{hlm}$.

Hartoko, A., P. Soedarsono, dan A. Indrawati. 2013. Analisa Klorofil- $\alpha$, Nitrat dan Fosfat pada Vegetasi Mangrove Berdasarkan Data Lapangan dan Data Satelit Geoeye di Pulau Parang, Kepulauan Karimunjawa. Management of Aquatic Resources. Volume 2 (2): 28-37.

Kuenzer, C., A. Bluemel, S. Gebhardt, T.V. Quoc, and S. Dech. 2011. Remote Sensing of Mangrove Ecosystems: A Review. Remote Sens, 3: 878-928.

Kushartono, E.W. 2009. Beberapa Aspek Bio-Fisik Kimia Tanah di Daerah Mangrove Desa Pasar Banggi Kabupaten Rembang. Ilmu Kelautan. Volume 14 (2):76-83.

Libes, S.M. 1992. An Introduction to Marine Biogeochemistry. John Wiley and Sons Inc. New York. $928 \mathrm{hlm}$.

Nugroho, R.A., S. Widada, dan R. Pribadi. 2013. Studi Kandungan Bahan Organik dan Mineral (N, P, K, Fe, dan Mg) Sedimen di Kawasan Mangrove Desa Bedono, Kecamatan Sayung, Kabupaten Demak. Journal of Marine Research. Volume 2(1):62-70.

Odum, E.P. 1993. Dasar-Dasar Ekologi. Gadjah Mada Press. Yogyakarta. (diterjemahkan oleh Tj. Samigan). 697 hlm.

Pantjara, B., M. Mangampa, dan R. Syah. 2010. Budidaya Udang Windu Penaeus monodon pada Tambak Tanah Sulfat Masam di Tarakan, Kalimantan Timur. Jurnal Perikanan. Volume 12(1): 1-10.

Poppo, A., Mahendra, M.S., dan Sundra, I.K. 2009. Studi Kualitas Perairan Pantai di Kawasan Industri Perikanan, Desa Pengambean, Kecamatan Negara, Kabupaten Jembrana. Ecotrophic. Volume 3(2):98103.

Purnomo, P.W., M. Nitisupardjo, dan Y. Purwandari. 2013. Hubungan Antara Total Bakteri Dengan Bahan Organik, $\mathrm{NO}_{3}$ dan $\mathrm{H}_{2} \mathrm{~S}$ pada Lokasi Sekitar Eceng Gondok dan Perairan Terbuka Di Rawa Pening. Management of Aquatic Resources. Volume 2 (3): 85-92.

Roswaty, S., M. R. Muskananfola, dan P. W. Purnomo. 2014. Tingkat Sedimentasi di Muara Sungai Wedung Kecamatan Wedung, Demak. Management of Aquatic Resources. Volume 3(2): 129-137.

Sulistiyowati, H. 2009. Biodiversitas Mangrove di Cagar Alam Pulau Sempu. Jurnal Sainstek. Volume 8 (1):5961.

Suwardi, E. Tambaru, Ambeng, dan D. Priosambodo. 2014. Keanekaragaman Jenis Mangrove di Pulau Panikiang Kabupaten Barru Sulawesi Selatan. Fakultas Matematika dan Ilmu Pengetahuan Alam, Universitas Hasanuddin, Makassar. $9 \mathrm{hlm}$.

Triani, W., A. Pangastuti, dan O.P. Astirin. 2005. Populasi Bakteri Pengoksidasi Sulfur Anorganik dan Kadar $\mathrm{H}_{2} \mathrm{~S}$ di Tambak Udang Putih (Panaeus vannamei Boone) Sistem Intensif. Jurnal Biosmart. Volume 7 (1): 23-26. 